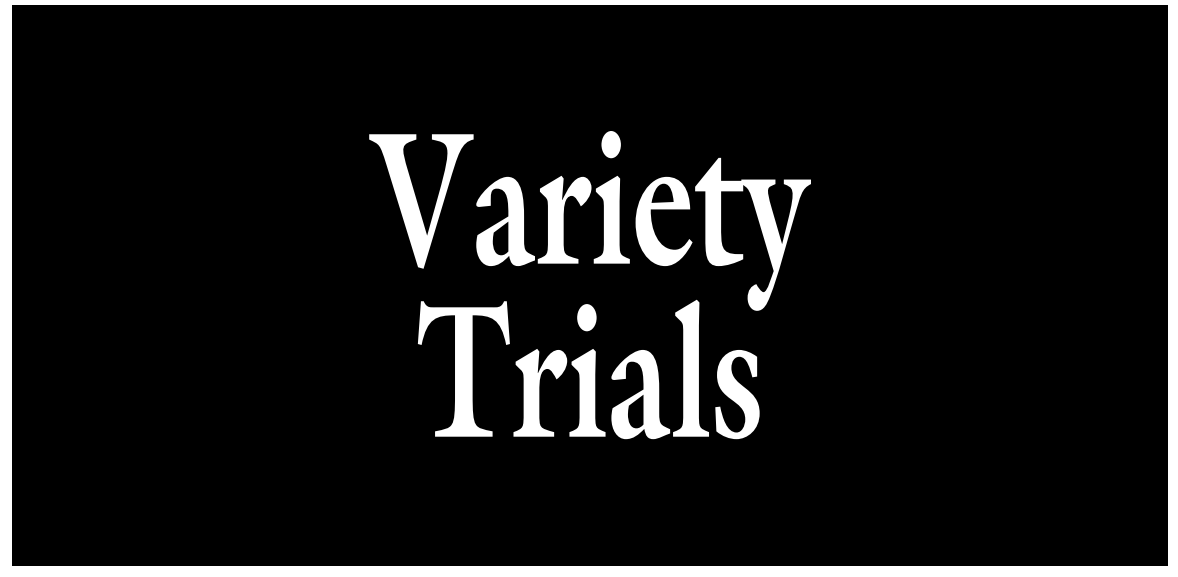

\title{
Basil Performance Evaluation in Aquaponics
}

\author{
Rhuanito Soranz Ferrarezi ${ }^{1,3}$ and Donald S. Bailey ${ }^{2}$
}

ADDITIONAL INDEX WORDs. aquaculture, cultivar trial, herbs, hydroponics, recirculating system, tropics

Summary. Basil (Ocimum sp.) is a fast-growing, high-value cash crop for aquaponics. Plant suitability evaluation in tropical conditions is critical to recommend new cultivars, increasing grower portfolio and minimizing the production risks associated with untested selections. Two trials were conducted to identify suitable basil cultivars for tropical outdoor aquaponics production using the University of the Virgin Islands (UVI) Commercial Aquaponics System in the U.S. Virgin islands. We evaluated five basil cultivars in Summer 2015 (Genovese, Lemon, Purple Ruffles, Red Rubin, and Spicy Globe), and seven cultivars in Fall 2015 (Cinnamon, Genovese, Lemon, Purple Ruffles, Red Rubin, Spicy Globe, and Thai). In both trials, 3-week-old seedlings were transplanted in net pots at a density of 1.5 plants $/ \mathrm{ft}^{2}\left(16.15\right.$ plants $\left./ \mathrm{m}^{2}\right)$. The 6 -inch portions and upper portions of the canopy were harvested as a salable product and the resultant material (leaves and stems) considered as total yield per square meter. In the summer, yield was higher in 'Genovese' $\left(14.91 \mathrm{~kg} \cdot \mathrm{m}^{-2}\right)$ and 'Spicy Globe' (13.99 $\left.\mathrm{kg} \cdot \mathrm{m}^{-2}\right)$; 'Purple Ruffles' resulted in the lowest yield $\left(4.18 \mathrm{~kg} \cdot \mathrm{m}^{-2}\right)$. Leaf anthocyanin was greater for the red cultivars Red Rubin [28.35 anthocyanin content index (ACI)] and Purple Ruffles (34.36 ACI) compared with the other cultivars. Chlorophyll content was the highest in 'Genovese' [48.59 chlorophyll content index (CCI)]. In the fall, 'Cinnamon' $\left(6.60 \mathrm{~kg} \cdot \mathrm{m}^{-2}\right)$, 'Genovese' $\left(6.70 \mathrm{~kg} \cdot \mathrm{m}^{-2}\right)$, and 'Spicy Globe' $(6.35$ $\left.\mathrm{kg} \cdot \mathrm{m}^{-2}\right)$ showed the highest yield and 'Purple Ruffles' the lowest $\left(1.68 \mathrm{~kg} \cdot \mathrm{m}^{-2}\right)$. Leaf anthocyanin differed in all cultivars, with the higher values in Purple Ruffles $\mathbf{8 0 . 5}$ $\mathrm{ACI}$ ) and Red Rubin (36.5 ACI). Chlorophyll content was a response of plant growth and cultivar, with values increasing over time and ranging from 12.06 (Lemon) to 17.99 CCI (Cinnamon). Plant growth index (PGI) was higher than that of other cultivars in Genovese and Lemon on day 58 (summer), and higher in Cinnamon on day 87 (fall). Yield was greater during the summer, which was calculated from May to August, in comparison with the fall, calculated from September to November. Yield declined for the fourth harvest in the summer, indicating that growers may need to end production after the third harvest and replant the crop. The results of this experiment indicate that basil has potential as a specialty, short-season, and high-value crop in the UVI Commercial Aquaponics System. Of the cultivars tested, Genovese and Spicy Globe were the highest yielding cultivars within the environmental and geographical conditions of this study for two consecutive seasons (summer and fall).

A quaponics is a food production technology that combines aquaculture and hydroponics in an integrated recirculating system without soil (Rakocy et al., 2006). The aquaponics ecosystem is composed by fish, bacteria, and plants (Somerville et al., 2014). Fish are fed with dry feed; hydroponically (Rakocy et al., 2011). Solid fish waste eliminated after food digestion provides most of the nutrients required for plant nutrition, except calcium and iron, which are commonly supplemented. The aquaculture effluent flows through deepflow culture hydroponic troughs, and a closed system recirculates the water back to the fish-rearing tanks for reuse (Rakocy et al., 2011).

The integration of fish and vegetable production in the UVI Commercial Aquaponics System uses a small land area, conserves water, limits waste discharged into the environment (Boxman et al., 2017), and recovers nutrients from fish production into valuable vegetable crops. A standard protocol has been developed for the production of Nile tilapia (Oreochromis niloticus), which yields up to $11,000 \mathrm{lb}$ per annum (Rakocy et al., 2006). The production of many vegetable crops also has been studied, but because of specific growth patterns and differences of marketable product, no single protocol is promoted.

In general, leafy vegetables grow well with the abundant nitrogen in the system, have a short production period, and are in high demand. Lettuce (Lactuca sativa) has been produced continuously in the UVI Commercial Aquaponics System, including a diversity of cultivars and cultural practices (Rakocy et al., 1997). Economic studies of lettuce and basil production also have been conducted (Bailey et al., 1997; Rakocy et al., 2004a). Each crop yields different revenue per unit area, and this variation must be considered when selecting cultivars to produce and obtain the highest returns for the farmer (Bailey and Ferrarezi, 2017).

Basil is a fast-growing crop commonly cultivated in aquaponics systems by commercial producers, hobbyists, and educators (Love et al., 2014). The crop's distinctive aroma and flavor derive from essential oils, plant phenolics, flavonoids, and phenylpropanoids (Juliani and Simon, 2002). The genus Ocimum comprises more than 30 species, and is divided into basil types, which include sweet (Ocimum basilicum), lemon (Ocimum citriodorum), dwarf bush (Ocimum minimum), purple (O. basilicum var. purpurescens), and thai (O. basilicum var. thyrsiflorum). Basil cultivars can be produced for different target markets such as fish waste is generated by direct excre tion into the fish tanks, and organic waste metabolites are converted by microbial breakdown in the recirculating system filters-where ammonia is converted to nitrate by nitrifying bacteria (Love et al., 2014); and nutrients are absorbed by the plants cultivated 
essential oils, pharmaceuticals, ornamental plants, or as a culinary herb for fresh or dry spices (Kaurinovic et al., 2011; Walters and Currey, 2015). Purple basils contain higher anthocyanin levels (Simon et al., 1999) and are grown for culinary purposes and teas, especially as a potential source of anthocyanins because of antioxidant properties (Juliani and Simon, 2002). Basil can be produced in aquaponics using one planting date (batch) or staggered planting dates, resulting in the production of 7.8 and $7.2 \mathrm{~kg} \cdot \mathrm{m}^{-2}$ of shoot fresh weight, respectively, with a density of 8 plants $/ \mathrm{m}^{2}$ (Rakocy et al., 2004b).

Choosing high-value crops is one of the strategies to maximize income in aquaponics systems (Dediu et al., 2012), increasing grower portfolio and minimizing the production risks. Previous research has indicated that basil is a high-value crop for aquaponics (Rakocy et al., 2004b). However, little research has been conducted to produce different basil types and cultivars in commercialscale aquaponics (Love et al., 2015). Walters and Currey (2015) recently compared hydroponics systems and basil cultivars in greenhouse conditions with environmental control. Saha et al. (2016) cultivated basil under soilless agricultural systems (aquaponics vs. hydroponics), without indicating how different cultivars perform. The evaluation of plant adaptation in tropical conditions is essential to recommend new cultivars for the UVI Commercial Aquaponics System. Yield per area is a primary concern so that cultivars with the

Received for publication 7 June 2017. Accepted for publication 21 Dec. 2018.

Published online 11 February 2019.

We thank Luis Carino Jr. and Donna Gonzales (Horticulture and Aquaculture program) and the undergraduate students Seti Balkaran and Jomanni Bernier for technical assistance. This work is supported by the USDA National Institute of Food and Agriculture, Hatch project (accession number 226104).

${ }^{1}$ University of Florida, Institute of Food and Agricultural Sciences, Indian River Research and Education Center, Fort Pierce, FL 34945

${ }^{2}$ University of the Virgin Islands, Agricultural Experiment Station, RR\#1 Box 10000, Kingshill, VI 00850

${ }^{3}$ Corresponding author. E-mail: rferrarezi@ufl.edu.

This is an open access article distributed under the CC BY-NC-ND license (https://creativecommons.org/ licenses/by-nc-nd/4.0/).

https://doi.org/10.21273/HORTTECH03797-17
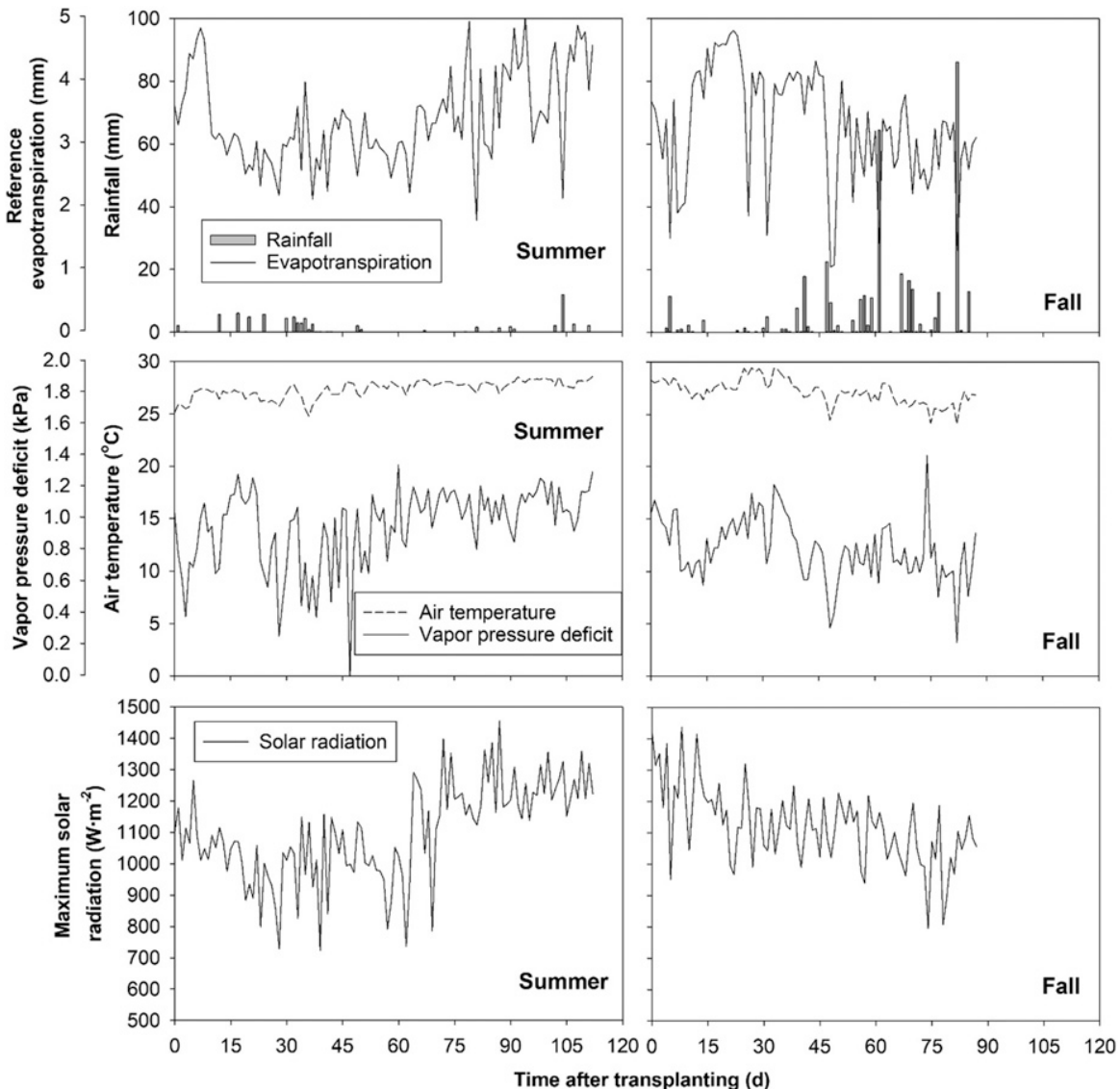

Fig. 1. Rainfall, reference evapotranspiration, average air temperature and vapor pressure deficit, and maximum solar radiation recorded in Kingshill, U.S Virgin Islands throughout the two growing seasons (Summer and Fall 2015) using an automated weather station (ET107; Campbell Scientific) located $100 \mathrm{ft}(30.5 \mathrm{~m})$ from the experiment site; $1 \mathrm{~mm}=0.0394 \mathrm{inch}, 1 \mathrm{kPa}=0.1450 \mathrm{psi},\left(1.8 \times{ }^{\circ} \mathrm{C}\right)+32={ }^{\circ} \mathrm{F}$, $1 \mathrm{~W} \cdot \mathrm{m}^{-2}=0.0929 \mathrm{~W} / \mathrm{ft}^{2}$.

greatest biomass can be selected to maximize the production per area. Plant height, width, leaf area, number of leaves, and other aspects of

plant morphology are also useful to evaluate crop performance. Our objective was to identify suitable basil cultivars for tropical outdoor aquaponics

\begin{tabular}{llll}
\hline $\begin{array}{l}\text { Units } \\
\begin{array}{l}\text { To convert U.S. to SI, } \\
\text { multiply by }\end{array}\end{array}$ & U.S. unit & SI unit & $\begin{array}{l}\text { To convert SI to U.S., } \\
\text { multiply by }\end{array}$ \\
\hline 0.4047 & $\mathrm{acre}(\mathrm{s})$ & $\mathrm{ha}$ & 2.4711 \\
0.3048 & $\mathrm{ft}$ & $\mathrm{m}$ & 3.2808 \\
0.0929 & $\mathrm{ft}^{2}$ & $\mathrm{~m}^{2}$ & 10.7639 \\
0.0283 & $\mathrm{ft}^{3}$ & $\mathrm{~m}^{3}$ & 35.3147 \\
3.7854 & gal & $\mathrm{L}$ & 0.2642 \\
0.7457 & horsepower & $\mathrm{kJ} \cdot \mathrm{s}^{-1}$ & 1.3410 \\
2.54 & inch $(\mathrm{es})$ & $\mathrm{cm}$ & 0.3937 \\
25.4 & inch $(\mathrm{es})$ & $\mathrm{mm}$ & 0.0394 \\
0.4536 & $\mathrm{lb}$ & $\mathrm{kg}$ & 2.2046 \\
4.8824 & $\mathrm{bm} / \mathrm{ft}^{2}$ & $\mathrm{~kg} \cdot \mathrm{m}^{-2}$ & 0.2048 \\
1 & $\mathrm{mmho} / \mathrm{cm}$ & $\mathrm{dS} \cdot \mathrm{m}^{-1}$ & 1 \\
28.3495 & $\mathrm{oz}$ & $\mathrm{g}$ & 0.0353 \\
305.1517 & $\mathrm{oz} / \mathrm{ft}^{2}$ & $\mathrm{~g} \cdot \mathrm{m}^{-2}$ & 0.0033 \\
7.4892 & $\mathrm{oz} / \mathrm{gal}$ & $\mathrm{g} \cdot \mathrm{L}^{-1}$ & 0.1335 \\
0.1 & $\mathrm{ppm}$ & $\mathrm{mg} / 100 \mathrm{~g}$ & 10 \\
1 & $\mathrm{ppm}$ & $\mathrm{mg} \cdot \mathrm{L}^{-1}$ & 1 \\
6.8948 & $\mathrm{psi}$ & $\mathrm{kPa}$ & 0.1450 \\
10.7639 & $\mathrm{~W} / \mathrm{ft}^{2}$ & $\mathrm{~W} \cdot \mathrm{m}^{-2}$ & 0.0929 \\
$\left({ }^{\circ} \mathrm{F}-32\right) \div 1.8$ & ${ }^{\circ} \mathrm{F}$ & ${ }^{\circ} \mathrm{C}$ & $\left({ }^{\circ} \mathrm{C} \times 1.8\right)+32$ \\
& & &
\end{tabular}




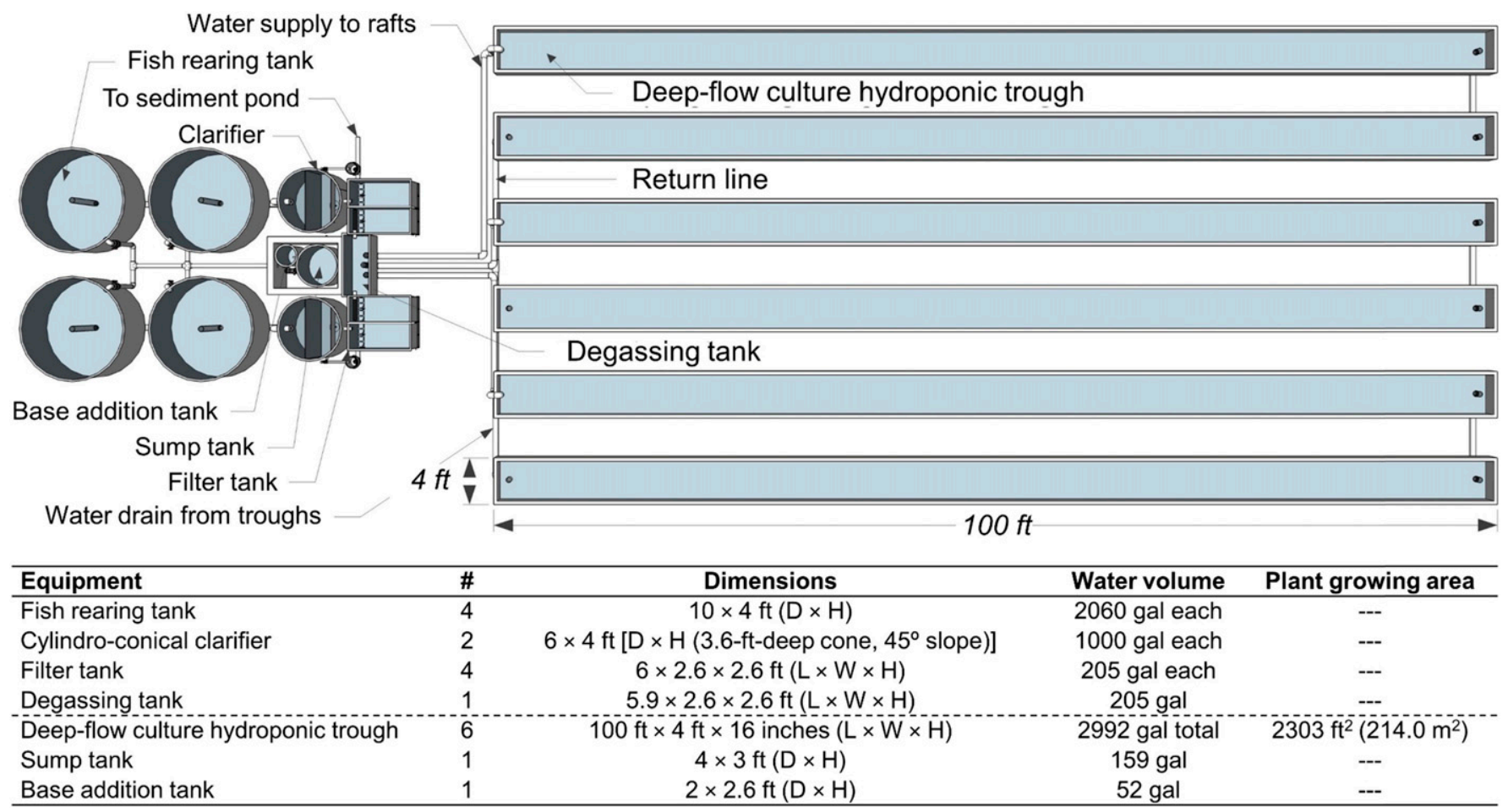

Fig. 2. The University of the Virgin Islands Commercial Aquaponics System, consisting of three main components: fishrearing tanks, solids removal [clarifier, filter tanks, and degassing tank (Red Ewald)], and deep-flow culture hydroponic troughs. Water returns to a sump, where a base can be added into the base-addition tank to adjust $\mathrm{pH} ; \mathrm{D}=$ diameter, $\mathrm{H}=$ height, $\mathrm{L}=$ length, $\mathrm{W}=$ width, $1 \mathrm{ft}=0.3048 \mathrm{~m}, 1$ inch $=2.54 \mathrm{~cm}, 1$ gal $=3.7854 \mathrm{~L}$.

production using the UVI Commercial Aquaponics System to support farmers picking adapted cultivars.

\section{Material and methods}

LOCATION AND ENVIRONMENTAL CONDITIONS. Basil cultivars were evaluated in two sequential seasons [Summer (22 Apr. to 12 Aug. 2015) and Fall (7 Sept. to 3 Dec. 2015)] at the UVI's Agricultural Experiment Station (AES), Kingshill, U.S. Virgin

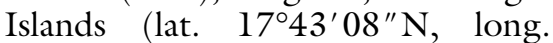
$64^{\circ} 47^{\prime} 46^{\prime \prime} \mathrm{W}$, elevation $100 \mathrm{ft}$ ). UVI AES is located on the island of St. Croix, U.S. Virgin Islands. The territory presents an equatorial climate with dry summers (As) according to Köppen-Geiger classification (Kottek et al., 2006).

Daily total rainfall, reference evapotranspiration (ETo), average air temperature and vapor pressure deficit (VPD), and maximum solar radiation were recorded throughout the studies using a weather station (ET107; Campbell Scientific, Logan, UT) (Fig. 1). The equipment was located $100 \mathrm{ft}$ from the experiment site. The average $\pm \mathrm{SD}$ for the two growing seasons (summer and fall) were, respectively: total

Table 1. Nutrient concentration in fish-rearing tank effluent in Summer and Fall 2015 used for the cultivation of basil ('Cinnamon', 'Genovese', 'Lemon', 'Purple Ruffles', 'Red Rubin', 'Spicy Globe', and 'Thai') in tropical conditions. Samples were collected from the University of the Virgin Islands Commercial Aquaponics System. Average of five samples per growing season.

\begin{tabular}{lrr}
\hline Variable & Summer & Fall \\
\hline $\mathrm{pH}$ & 6.87 & 6.69 \\
Electrical conductivity $\left(\mathrm{dS} \cdot \mathrm{m}^{-1}\right)$ & 0.69 & 0.65 \\
Nitrate-nitrogen $\left(\mathrm{mg} \cdot \mathrm{L}^{-1}\right)$ & 47.23 & 49.60 \\
Ammonium-nitrogen $\left(\mathrm{mg} \cdot \mathrm{L}^{-1}\right)$ & 0.44 & 1.85 \\
Phosphate $\left(\mathrm{mg} \cdot \mathrm{L}^{-1}\right)$ & 8.64 & 11.49 \\
Potassium $\left(\mathrm{mg} \cdot \mathrm{L}^{-1}\right)$ & 47.6 & 48.85 \\
Calcium $\left(\mathrm{mg} \cdot \mathrm{L}^{-1}\right)$ & 47.2 & 37.30 \\
Magnesium $\left(\mathrm{mg} \cdot \mathrm{L}^{-1}\right)$ & 11.77 & 14.58 \\
Sulfate $\left(\mathrm{mg} \cdot \mathrm{L}^{-1}\right)$ & 16.13 & 21.01 \\
Aluminum $\left(\mathrm{mg} \cdot \mathrm{L}^{-1}\right)$ & 0.01 & 0.09 \\
Boron $\left(\mathrm{mg} \cdot \mathrm{L}^{-1}\right)$ & 0.34 & 0.39 \\
Chloride $\left(\mathrm{mg} \cdot \mathrm{L}^{-1}\right)$ & 28.49 & 44.01 \\
Copper $\left(\mathrm{mg} \cdot \mathrm{L}^{-1}\right)$ & 0.09 & 0.07 \\
Iron $\left(\mathrm{mg} \cdot \mathrm{L}^{-1}\right)$ & 3.92 & 1.58 \\
Sodium $\left(\mathrm{mg} \cdot \mathrm{L}^{-1}\right)$ & 36.18 & 59.17 \\
Molybdenum $\left(\mathrm{mg} \cdot \mathrm{L}^{-1}\right)$ & 0.02 & 0.01 \\
Manganese $\left(\mathrm{mg} \cdot \mathrm{L}^{-1}\right)$ & 0.01 & 0.08 \\
Zinc $\left(\mathrm{mg} \cdot \mathrm{L}^{-1}\right)$ & 1.04 & 0.73 \\
\hline
\end{tabular}

${ }^{\mathrm{z}} 1 \mathrm{dS} \cdot \mathrm{m}^{-1}=1 \mathrm{mmho} / \mathrm{cm}, 1 \mathrm{mg} \cdot \mathrm{L}^{-1}=1 \mathrm{ppm}$.

rainfall 76 and $368 \mathrm{~mm}$; ETo $3.67 \pm$ 0.76 and $3.28 \pm 0.99 \mathrm{~mm}$; air temperature $27.37 \pm 0.81$ and $27.15 \pm$ $1.17^{\circ} \mathrm{C}$; VPD $0.95 \pm 0.25$ and $0.81 \pm$ $0.2 \mathrm{kPa}$ (calculated from the saturated and actual air vapor pressure using the air temperature and relative humidity data); and maximum solar radiation $1142 \pm 170$ and $1090 \pm$ $194 \mathrm{~W} \cdot \mathrm{m}^{-2}$. 
UVI COMMERCIAL AQUAPONICS system. The system used was developed by the UVI's Horticulture and Aquaculture program in St. Croix, and consisted of fish-rearing tanks, cylindro-conical clarifiers, filter tanks, degassing tank, deep-flow culture hydroponic troughs, sump tank, and base-addition tank (Rakocy et al., 2006, 2011) (details provided in Fig. 2). The water flow rate used in the study was $100 \mathrm{gal} / \mathrm{min}$, with a retention time of $3 \mathrm{~h}$. The entire system contained $\approx 29,000$ gal of water and occupied 1/8 acre (Rakocy et al., 2006). A 1.5-horsepower regenerative air blower (S45; Sweetwater, Apopka, FL) provided air to each rearing tank with twenty-two $6 \times 1.5 \times 1.5$-inch [length $(\mathrm{L}) \times$ width $(\mathrm{W}) \times$ height $(\mathrm{H})$ ] medium pore air diffusers (AS15L; Sweetwater). Hydroponic troughs were aerated with a l-horsepower regenerative air blower (S4I-A; Sweetwater) and twenty-four $3 \times 1 \times 1$-inch $(\mathrm{L} \times \mathrm{W} \times \mathrm{H})$ medium pore air diffusers (AS5L; Sweetwater) spaced at 4 - $\mathrm{ft}$ intervals in the center of the trough.

Dissolved oxygen, $\mathrm{pH}$, electrical conductivity (EC), and water temperature were measured daily throughout both production trials using a digital meter (HI98194; Hanna Instruments, Woonsocket, RI). There was no automated control of those parameters, but they were constant during the study (data not shown). Dissolved oxygen averaged (mean $\pm \mathrm{SD}) 4.90 \pm 0.81 \mathrm{mg} \cdot \mathrm{L}^{-1}, \mathrm{EC} 0.89 \pm 0.08$ $\mathrm{dS} \cdot \mathrm{m}^{-1}$, and water temperature $26.63 \pm$ $0.85{ }^{\circ} \mathrm{C} . \mathrm{pH}$ averaged $7.46 \pm 0.27$ and base addition was not required. Five pounds of chelated iron ( $11 \%$ FeDTPA; BR Global, Rocky Mount, NC) was added every 3 weeks to maintain a concentration of $2 \mathrm{mg} \cdot \mathrm{L}^{-1}$ iron. Calcium was applied weekly by foliar spraying 10 gal of a solution with $60 \mathrm{~g}$ calcium nitrate $(15.5 \%$ nitrogen and $19 \%$ calcium) per liter of water. Fish-rearing tank effluent nutrient concentrations during the trials are available in Table 1 . About $1.5 \%$ of the system water volume was replenished daily by using rainwater stored in four $30 \times 4$-ft [diameter $(\mathrm{D}) \times$ $\mathrm{H}]$ panel tanks (21,150 gal; Red Ewald, Karnes City, TX).

Nile tilapia were stocked at a rate of $77 \mathrm{fish} / \mathrm{m}^{3}$ and fed three times daily with a complete, floating-pelleted diet with $32 \%$ protein (PMI Aquamax, Gray Summit, MO). The feeding rate applied during the summer trial was $66 \mathrm{~g} \cdot \mathrm{m}^{-2}$ plant area per day, and during the fall trial was $74 \mathrm{~g} \cdot \mathrm{m}^{-2}$ plant area per day. Both feeding rates were within the optimum range of $60-100 \mathrm{~g} \cdot \mathrm{m}^{-2}$ plant area per day indicated by Rakocy et al. (2006) to prevent plant nutrient toxicity. The treatment capacity of the filters and hydroponic tanks is equivalent to $180 \mathrm{~g}$ feed per square meter of plant area per day. Fish growth performance was not assessed because of extensive results already published on that topic at the same system (Rakocy et al., 1997, 2004a, 2004b, 2006, 2011).

Treatments. In the summer, we tested five basil cultivars [Genovese (sweet basil), Lemon (lemon basil), Purple Ruffles and Red Rubin (purple basil), and Spicy Globe (bush basil)]. In the fall, we evaluated seven cultivars [Cinnamon (cinnamon basil), Genovese, Lemon, Purple Ruffles, Red Rubin, Spicy Globe, and Thai (thai basil)].

Procedures fOR EACH SEASON. Basil seeds (Johnny's Selected Seeds, Winslow, ME) were seeded on 98-cell flats (HC Companies, Middlefield,
$\mathrm{OH}$ ) filled with commercial peatbased substrate with sphagnum moss ( $75 \%$ to $85 \%$ ), perlite, and vermiculite (Promix BX Mycorrhizae; Premier Tech Horticulture, Rivière-du-Loup, QC, Canada). Three-week-old seedlings were inserted into $2 \times 2$-inch $(\mathrm{D} \times \mathrm{H})$ net pots (Pöppelmann, Löhne, Germany) to hold the rooted seedling and transplanted into Styrofoam rafts $[4 \mathrm{ft} \times 8 \mathrm{ft} \times 1.5$ inch $(\mathrm{L} \times \mathrm{W}$ $\times \mathrm{H})$ ] floating on the surface of the hydroponic troughs. Rafts were prepared for planting by painting the board surface with white nontoxic roof paint (Cool-Cote 22-DW-9; BLP Mobile Paints, Mobile, AL) and drilled with 1-7/8-inch diameter holes. Forty-eight plants were transplanted into an area of $32 \mathrm{ft}^{2}$ $\left(2.97 \mathrm{~m}^{2}\right)$. Planting density was 1.5 plants $/ \mathrm{ft}^{2}$ (16.15 plants $\left./ \mathrm{m}^{2}\right)$ spaced $8 \times 12$ inches. A 4 -inch edge was left along the rafts to provide equal spacing to all plants.

Pest management required spraying once weekly with Bacillus thuringiensis ssp. kurstaki strain ABTS-351, fermentation solids, spores, and insecticidal toxins (Dipel DF; Valent Biosciences, Libertyville, IL) to control caterpillars (Lepidoptera), and with insecticidal soap potassium salts of fatty acids (M-Pede; Dow AgroSciences, Indianapolis, IN) to control aphids (Aphis sp.) and silverleaf whiteflies (Bemisia tabaci).

Measurements. Plants were harvested multiple times by cutting stems 6 inches above the substrate surface and allowing the plant to regrow until the next harvest. The upper part of the canopy (leaves and stems) was harvested as a salable product, and the resultant material

Table 2. Analyses of variance for yield, canopy fresh and dry weight, plant growth index (PGI), anthocyanin, and chlorophyll content for two seasons (Summer and Fall 2015) and seven basil cultivars (Cinnamon, Genovese, Lemon, Purple Ruffles, Red Rubin, Spicy Globe, and Thai) cultivated in the University of the Virgin Islands Commercial Aquaponics System.

\begin{tabular}{|c|c|c|c|c|c|c|}
\hline \multirow[b]{3}{*}{ Source } & \multicolumn{3}{|c|}{ Summer } & \multicolumn{3}{|c|}{ Fall } \\
\hline & Yield & Canopy fresh wt & Canopy dry wt & Yield & Canopy fresh wt & Canopy dry wt \\
\hline & \multicolumn{6}{|c|}{$P$ value } \\
\hline & PGI $^{\mathrm{z}}$ & Anthocyanin ${ }^{y}$ & Chlorophylly $^{y}$ & PGI & Anthocyanin & Chlorophyll \\
\hline Source & \multicolumn{6}{|c|}{$P$ value } \\
\hline Cultivar $\times$ sampling date & $<0.001$ & 0.903 & 0.624 & 0.002 & $<0.001$ & 0.119 \\
\hline
\end{tabular}

${ }^{\mathrm{z}}$ Calculated using plant height and width in two directions measured before each harvest in four plants [ (height + width $1+$ width 2$\left.) / 3\right]$ and collected on days $28,56,84$, and 112 in the summer and days $25,43,66$, and 87 in the fall.

${ }^{y}$ Data were collected on days 100 and 107 in the summer and on days $21,43,66$, and 87 in the fall. 
summed over time and totalized as yield per square meter. In the summer, plants were harvested every 4 weeks or $28 \mathrm{~d}$ (days $28,56,84$, and 112); and in the fall plants were harvested about every 3 weeks, ranging from 21 to $28 \mathrm{~d}$ (days $21,25,43$, 49,66 , and 87). The change in harvest interval was performed to suppress bolting-given that bolting produces an undesirable flavor on some cultivars (Gil, 2016).

Plant height and width (measured in two perpendicular directions) were measured before each
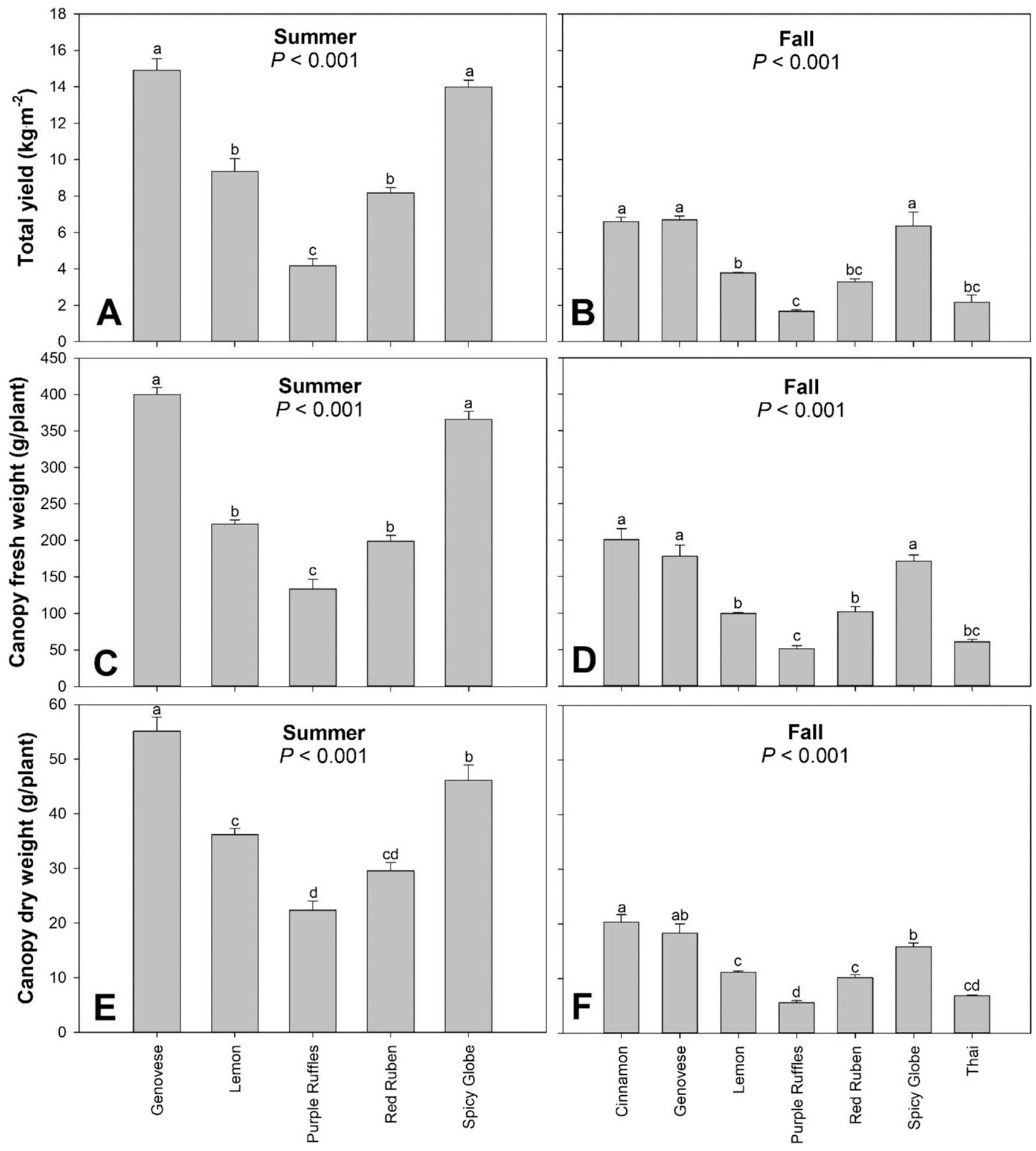

Fig. 3. Total yield (A and B), canopy fresh weight ( $C$ and $D$ ) and dry weight ( $E$ and $F$ ) in Summer and Fall 2015 for seven basil cultivars (Cinnamon, Genovese, Lemon, Purple Ruffles, Red Rubin, Spicy Globe, and Thai) cultivated in tropical conditions using the University of the Virgin Islands Commercial Aquaponics System. Means \pm sE followed by the same lowercase letter are not significantly different by Tukey's multiple comparisons test at $P<0.01 ; 1 \mathrm{~kg} \cdot \mathrm{m}^{-2}=0.2048 \mathrm{lb} / \mathrm{ft}^{2}, 1 \mathrm{~g}=0.0353 \mathrm{oz}$. 
harvest in four plants to calculate PGI $[(\mathrm{H}+\mathrm{Wl}+\mathrm{W} 2) \div 3]$ on days 28,56 , 84 , and 112 in the summer, and days $25,43,66$, and 87 in the fall.

Two entire plants were sampled from each cultivar at each harvest to determine canopy fresh and dry weight. We added the fresh weight of those two plants into the total yield results to avoid subestimation.

Anthocyanin and chlorophyll content indexes (nondestructive analysis) were measured on fully expanded leaves in two plants before the final harvest in the summer (days 100 and 107) and before each harvest in the fall (days 21,
43, 66, and 87). Anthocyanin was measured with a portable anthocyanin content meter (ACM-200 plus; OptiSciences, Hudson, NH), and chlorophyll using a chlorophyll concentration meter (MC-100; Apogee Instruments, Logan, UT), both following the manufacturer's instruction manuals.

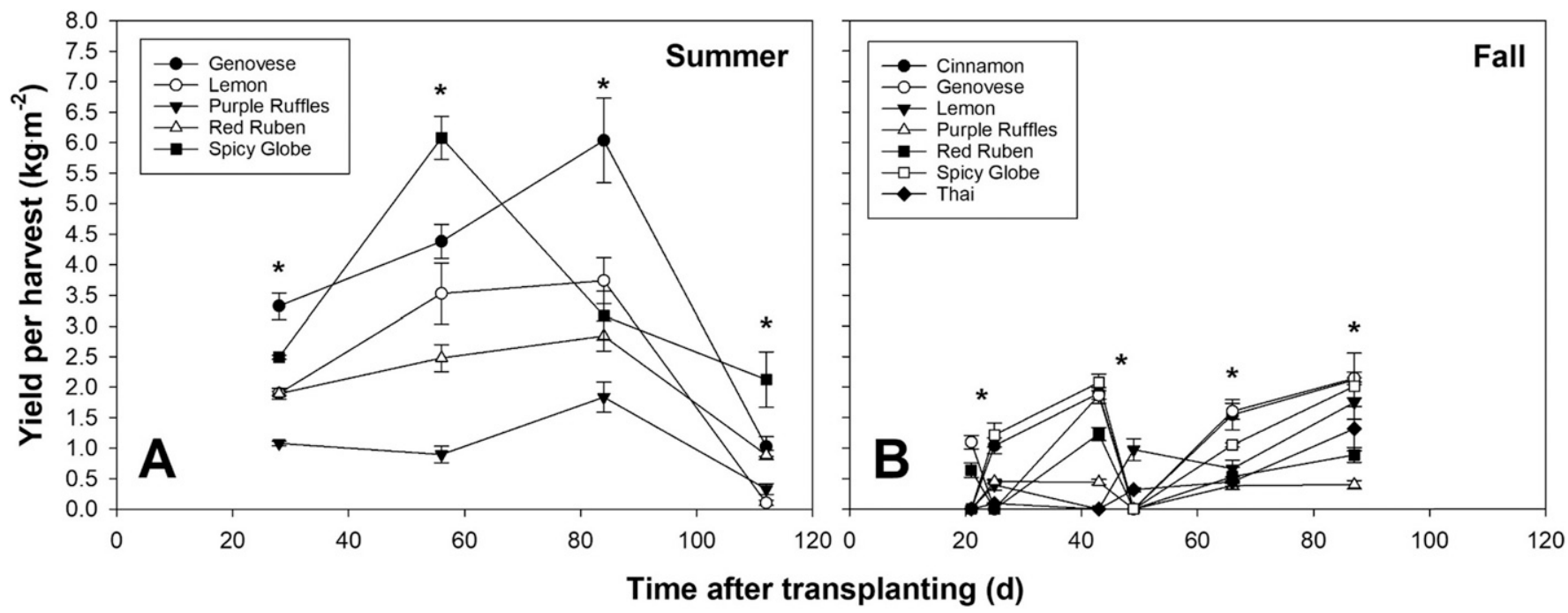

Fig. 4. Yield per harvest in Summer (A) and Fall 2015 (B) for basil cultivars (Cinnamon, Genovese, Lemon, Purple Ruffles, Red Rubin, Spicy Globe, and Thai) cultivated in tropical conditions using the University of the Virgin Islands Commercial Aquaponics System. Means $\pm \mathrm{SE}$ with * are significantly different by Tukey’s multiple comparisons test at $P<0.01 ; 1 \mathrm{~kg} \cdot \mathrm{m}^{-2}=$ $0.2048 \mathrm{lb} / \mathrm{ft}^{2}$.
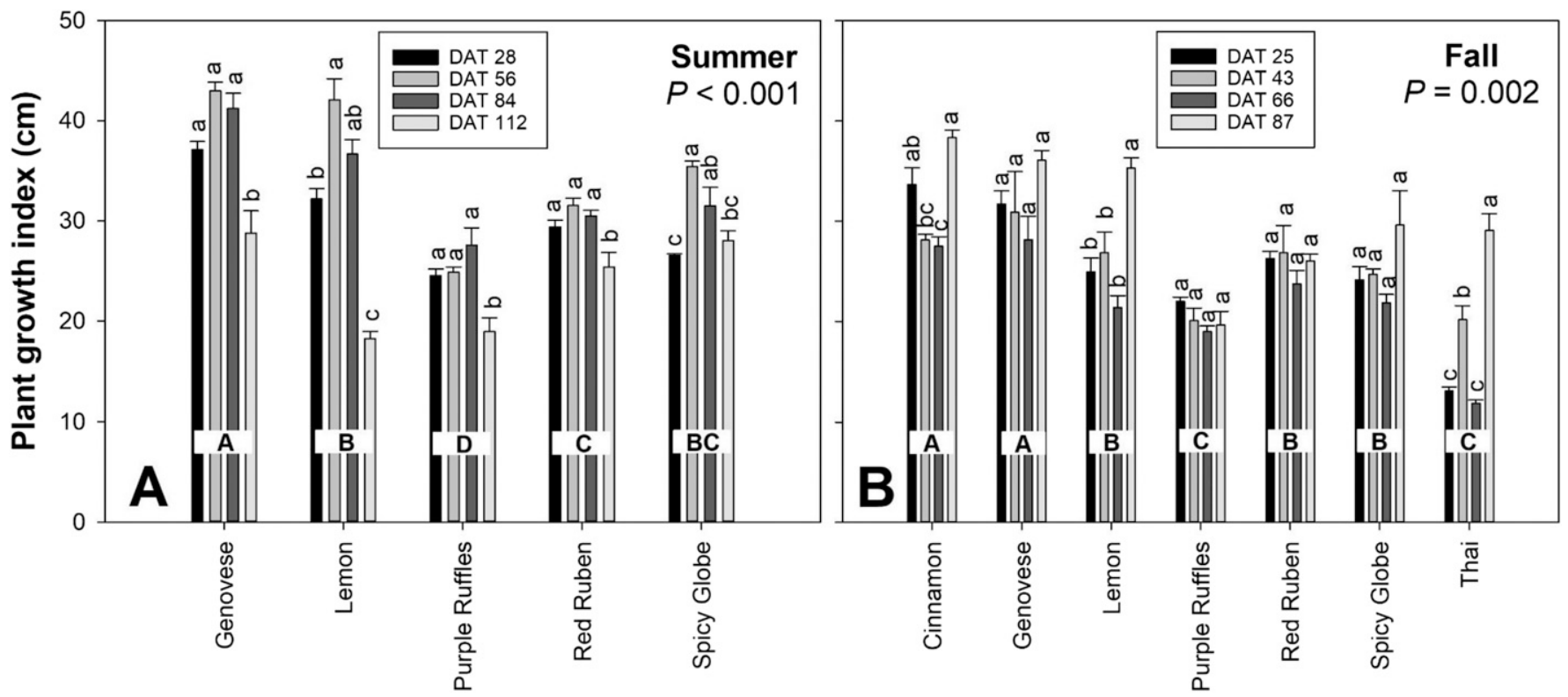

Fig. 5. Plant growth index (PGI) in Summer (A) and Fall 2015 (B) for seven basil cultivars (Cinnamon, Genovese, Lemon, Purple Ruffles, Red Rubin, Spicy Globe, and Thai) cultivated in tropical conditions using the University of the Virgin Islands Commercial Aquaponics System. PGI calculated using plant height and width in two directions measured before each harvest in four plants [ (height + width $1+$ width 2$) / 3$ ] and collected on days $28,56,84$, and 112 in the summer and days $25,43,66$, and 87 in the fall. Means \pm SE followed by the same letters are not significantly different by Tukey's multiple comparisons test at $P<0.01$. Lowercase letters represent the mean separation across sampling date within a cultivar, and uppercase letters within a cultivar across sampling date; DAT $=$ days after transplant, $1 \mathrm{~cm}=0.3937$ inch. 
Experimental Design AND STATISTICAL ANALYsis. Treatments were arranged in a randomized complete block design, with four replications in the summer and three replications in the fall. Data were analyzed using the general linear model procedures in SAS (version 9.4; SAS Institute, Cary, NC). A one-way analysis of variance model was used to determine treatment effects for total yield, and canopy fresh and dry weight. Repeated measures were used for PGI, anthocyanin, and chlorophyll content. The errors were checked to be normally and independently distributed. Probability values were considered statistically significant when $P \leq 0.01$.

\section{Results and discussion}

Our results indicate that basil adapted well to aquaponics in tropical warm conditions, because the yield was higher than that in other studies on hydroponics at northern U.S. regions using the same yield per area index (Walters, 2015). There were significant differences among the basil cultivars tested $[P<0.001$ (Table 2)]. In the summer, 'Genovese' (14.91 $\mathrm{kg} \cdot \mathrm{m}^{-2}$ ) and 'Spicy Globe' (13.99 $\mathrm{kg} \cdot \mathrm{m}^{-2}$ ) presented the highest total yield and 'Purple Ruffles' the lowest $\left(4.18 \mathrm{~kg} \cdot \mathrm{m}^{-2}\right)[P<0.001$ (Fig. 3A)].
Our results are comparable with Rakocy et al. (2004a) at $14.20 \mathrm{~kg} \cdot \mathrm{m}^{-2}$ (Spring 2002), and Rakocy et al. $(2004 \mathrm{~b})$ at $14.40 \mathrm{~kg} \cdot \mathrm{m}^{-2}$ (Summer/ Fall 2002) of 'Genovese' on a staggered planting in the same system. However, visual observations indicated the occurrence of bolting in some cultivars during the 4-week harvesting period (data not shown).

In the fall, 'Genovese' $(6.70$ $\left.\mathrm{kg} \cdot \mathrm{m}^{-2}\right)$, 'Cinnamon' $\left(6.60 \mathrm{~kg} \cdot \mathrm{m}^{-2}\right)$, and 'Spicy Globe' $\left(6.35 \mathrm{~kg} \cdot \mathrm{m}^{-2}\right)$ produced the highest total yield and 'Purple Ruffles' the lowest (1.68 $\left.\mathrm{kg} \cdot \mathrm{m}^{-2}\right)[P<0.001$ (Fig. 3B)]. One can note that total yield decreased $57 \%$ from the summer to fall $[P<$ 0.001 (Fig. 3A and B)]. Possibly, the more frequent cutting to avoid bolting stressed the plants and resulted in the decrease in total yield because morphological characteristics such as branching change when shoots are harvested several times (Walters and Currey, 2015). The reason for this difference is unknown because variation in nutrient concentration on fishrearing tank effluents cannot explain the decrease in total yield. Ammonium, aluminum, sodium, and chloride increased from the summer to fall, whereas copper, iron, molybdenum, and zinc decreased (Table 1); but the values were within recommended values (Kamal and Mair, 2005; Timmons and Ebeling, 2002). There were no detected visual nutrient deficiencies or diseases such as pythium root rot (Pythium sp.) or phytophthora root rot (Phytophthora sp.) over time to explain the total yield decrease. The cultivars tested in the summer presented the same trend in the fall, indicating that the total yield differences across cultivars were consistent in both seasons and mainly affected by cultivar differences.

Yield per harvest was greater during the summer than fall $[P<$ 0.001 (Fig. 4A)]. Yield declined on the fourth harvest in the summer, possibly because of plant senescence caused by successive harvests. This trend indicates that a grower may end the crop after the third harvest and replant. Rakocy et al. (2004b) did not report a decrease in 'Genovese' yield on the fourth harvest. Maybe, slight changes in the environmental conditions might have contributed to the reduced yield. The fall trial was conducted from September to November, with high temperatures at the beginning of the trial (Fig. 1). Because staggered plants grow slowly after transplant (Rakocy et al., 2004b), maybe the higher temperatures during basil's young phase affected subsequent plant growth.
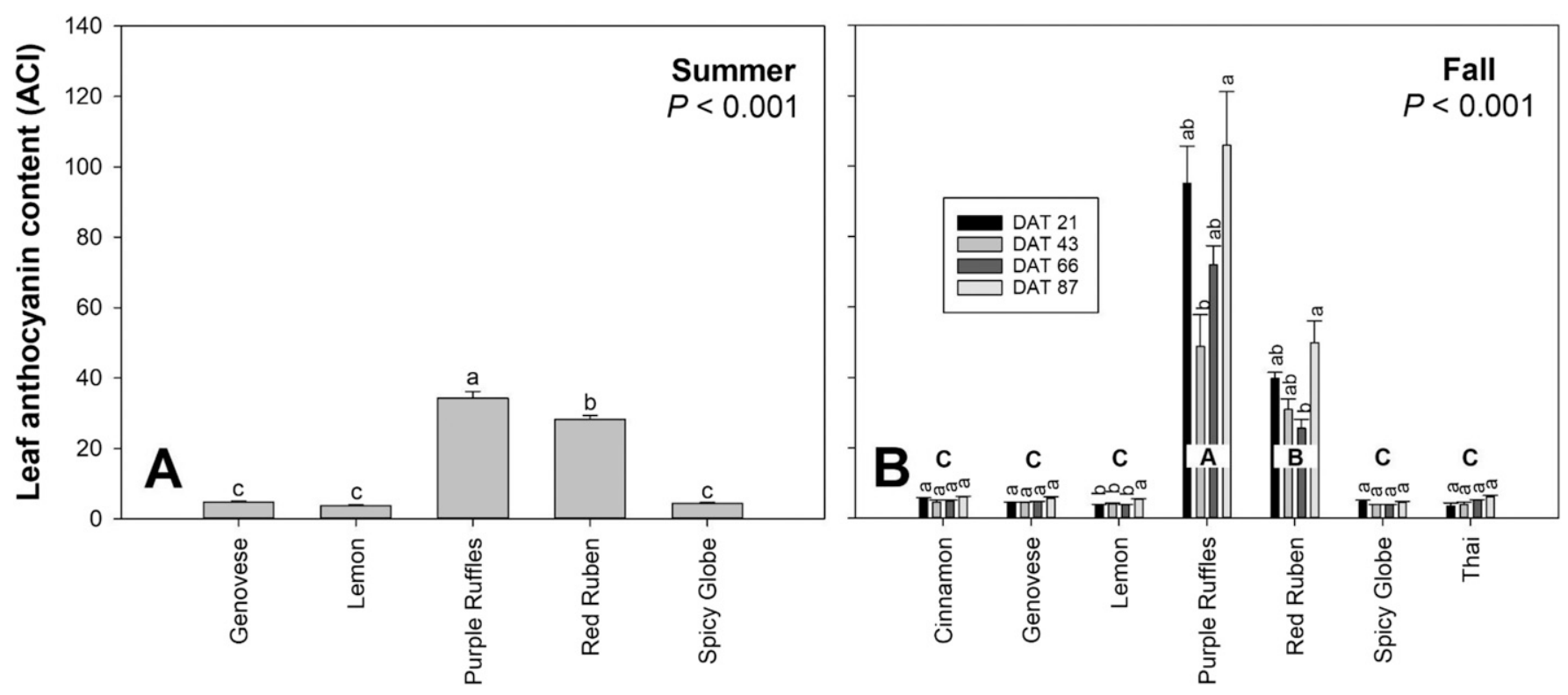

Fig. 6. Leaf anthocyanin content in Summer (A) and Fall 2015 (B) for seven basil cultivars (Cinnamon, Genovese, Lemon, Purple Ruffles, Red Rubin, Spicy Globe, and Thai) cultivated in tropical conditions using the University of the Virgin Islands Commercial Aquaponics System. Means \pm sE followed by the same letters are not significantly different by Tukey's multiple comparisons test at $\boldsymbol{P}<\mathbf{0 . 0 1}$. For the fall, lowercase letters represent the mean separation across sampling date within a cultivar, and uppercase letters within a cultivar across sampling date. Anthocyanin content index (ACI) was determined nondestructively using a handheld meter (ACM-200 plus; Opti-Sciences); DAT = days after transplant. 
Canopy fresh and dry weights were also influenced by cultivar $[P<$ 0.001 (Table 2)]. Average canopy fresh weight decreased $53 \%$ and dry weight decreased $67 \%$ from the summer to fall. Canopy fresh weight followed the same trend compared with total yield in the summer or fall trials $[P<0.001$ (Fig. 3C and D)]. Canopy dry weight was the highest in 'Genovese' (55.1 g/plant) in the summer $[P<0.001$ (Fig. 3E) $]$ and in 'Cinnamon' $(20.3 \mathrm{~g} / \mathrm{plant})$ in the fall $[P<0.001$ (Fig. $3 \mathrm{~F}$ ) $]$. To the best of our knowledge, few studies are available on aquaponics basil production. Besides UVI studies (Rakocy et al., 2004a, 2004b, 2006, 2011), most references compare aquaponics to hydroponics (Saha et al., 2016) or cultivate different basil cultivars in hydroponics systems (Walters and Currey, 2015), limiting data comparison.

Plant growth index was influenced by cultivars $\times$ sampling date in the summer and fall $[P<0.001$ and $P=0.002$, respectively (Table 2 )] Plant growth index was higher in 'Genovese' and 'Lemon' on day 56 in comparison with the other cultivars
$[P<0.001$ (Fig. 5A)] (summer), and in Cinnamon on day $87[P=0.002$ (Fig. 5B)] (fall). 'Purple Ruffles' was the smallest cultivar. Future trials could plant this cultivar at higher densities to increase yield per unit area (Walters, 2015). These results are in agreement with Walters and Currey (2015) and Simon et al. (1999). Average PGI decreased 16\% from the summer to fall.

Leaf anthocyanin content varied across cultivars in the summer, and cultivar and sampling date interaction in the fall $[P<0.001$ (Table 2)]. In

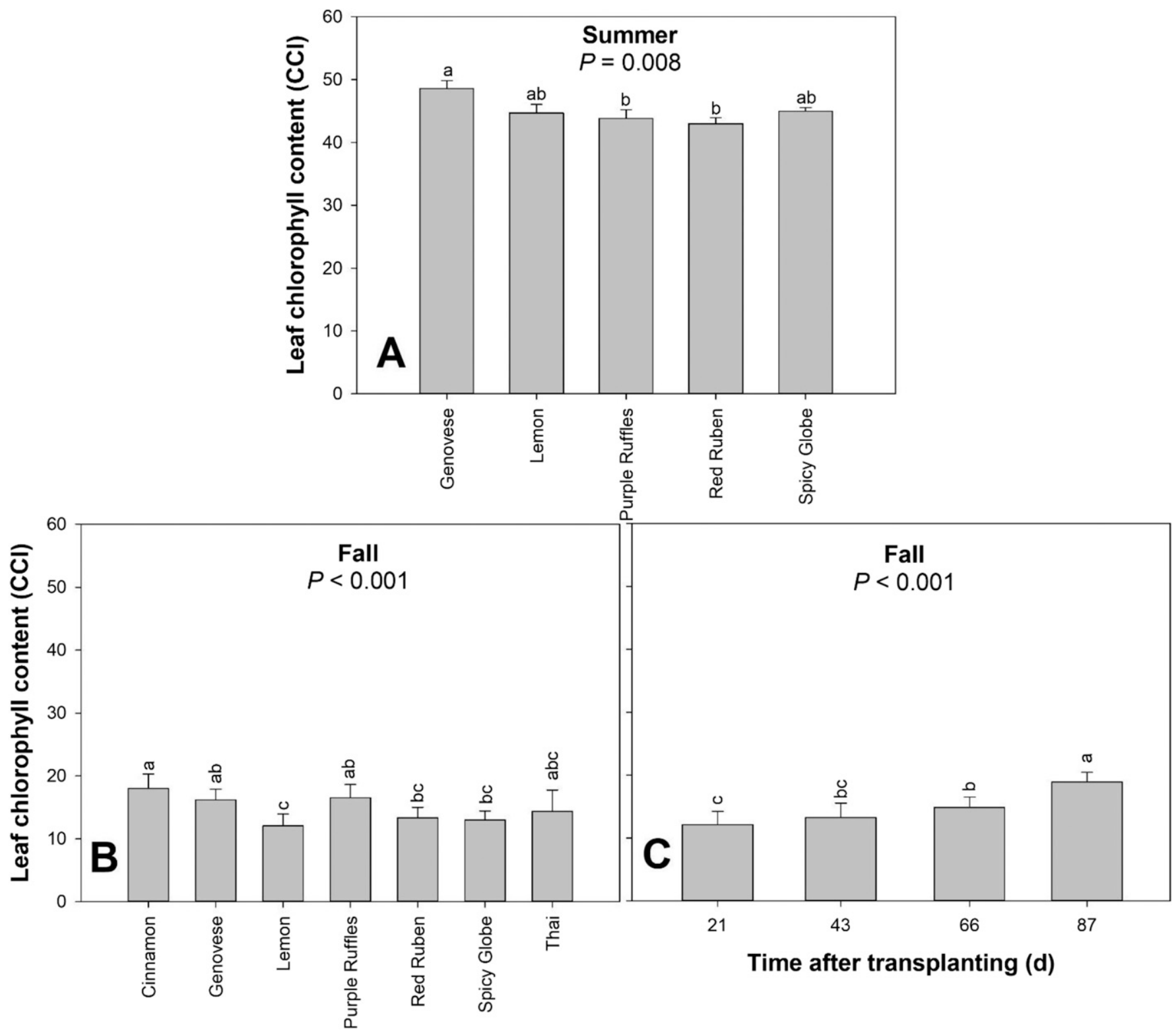

Fig. 7. Leaf chlorophyll content in Summer (A) and Fall 2015 (B and C) for seven basil cultivars (Cinnamon, Genovese, Lemon, Purple Ruffles, Red Rubin, Spicy Globe, and Thai) cultivated in tropical conditions using the University of the Virgin Islands Commercial Aquaponics System. Means \pm SE followed by the same lowercase letter are not significantly different by Tukey's multiple comparisons test at $P \leq 0.01$. Chlorophyll content index (CCI) was determined nondestructively using a handheld meter (MC-200 plus; Apogee Instruments). 
the summer, leaf anthocyanin was higher in the red cultivars Red Rubin $(28.35 \mathrm{ACI})$ and Purple Ruffles (34.36 ACI) $[P<0.001$ (Fig. 6A)]. In the fall, leaf anthocyanin differed in all cultivars, with higher values in 'Purple Ruffles' (80.5 ACI) and 'Red Rubin' (36.5 ACI) than in the green cultivars $[P<0.001$ (Fig. 6B)]. Phippen and Simon (2000) indicated that the genes controlling anthocyanin expression in purple basil cultivars are unstable, with the crops easily reverting to green pigments. This characteristic might have caused the reduced readings in each harvest in the fall $[P<$ 0.001 (Fig. 6B)]. Usually, 'Purple Ruffles' and 'Red Rubin' present a similar total extractable anthocyanin yield, averaging $17.75 \mathrm{mg} / 100 \mathrm{~g}$ of fresh tissue (Phippen and Simon, 1998; Simon et al., 1999). However, we measured anthocyanin using a nondestructive method (ACM-200 plus); and there are no reported results in the literature for comparison because data are not available for basil. Average leaf anthocyanin was $24 \%$ higher in the summer than in the fall.

Leaf chlorophyll content was influenced by cultivar in the summer $[P=0.008$ (Table 2)], and cultivar and sampling date interaction in the fall $[P<0.001$ (Table 2)]. Chlorophyll content was higher in 'Genovese' $(48.59 \mathrm{CCI})$ in the summer $[P=$ 0.008 (Fig. 7A)], and was a response of cultivar in the fall, with the highest index in Cinnamon (17.99 CCI) and the lowest in Lemon (12.06) $[P<$ 0.001 (Fig. 7B)]. Leaf chlorophyll values increased over time after transplant, maybe as a result of plant growth and chlorophyll accumulation $[P<0.001$ (Fig. 7C)]. However, average leaf chlorophyll content decreased $67 \%$ from the summer to fall.

\section{Conclusions}

Results of this experiment indicate that basil has potential as a specialty, short-season, and high-value crop in the UVI Commercial Aquaponics System. Of the cultivars tested, Genovese and Spicy Globe were the highest yielding selections within the environmental and geographical conditions of this study for two consecutive seasons (summer and fall). However, yield was higher in the summer compared with the fall, indicating a preferable season for basil cultivation in the U.S. Virgin Islands.

\section{Literature cited}

Bailey, D.S. and R.S. Ferrarezi. 2017. Valuation of vegetable crops produced in the UVI commercial aquaponics system. Aquacult. Rpt. 7:77-82.

Bailey, D.S., J.E. Rakocy, W.M. Cole, and K.A. Shultz. 1997. Economic analysis of a commercial-scale aquaponic system for the production of tilapia and lettuce, $\mathrm{p}$. 603-612. In: K. Fitzsimmons (ed.). Tilapia aquaculture. Proc. Fourth Intl. Symp. Tilapia Aquacult., Orlando, FL.

Boxman, S.E., Q. Zhang, D.S. Bailey, and M.A. Trotz. 2017. Life cycle assessment of a commercial-scale freshwater aquaponic system. Environ. Eng. Sci. 34:299-311.

Dediu, L., V. Cristea, and Z. Xiaoshuan. 2012. Waste production and valorization in an integrated aquaponic system with bester and lettuce. Afr. J. Biotechnol. 11:2349-2358.

Gil, M.I. 2016. Preharvest factors and fresh-cut quality of leafy vegetables. Acta Hort. 1141:57-64.

Juliani, H.R. and J.E. Simon. 2002. Antioxidant activity of basil, p. 575-579. In: J. Janick and A. Whipkey (eds.). Trends in new crops and new uses. ASHS Press, Alexandria, VA.

Kamal, A.H.M.M. and G.C. Mair. 2005. Salinity tolerance in superior genotypes of tilapia, Oreochromis niloticus, Oreochromis mossambicus and their hybrids. Aquaculture 247:189-201.

Kaurinovic, B., M. Popovic, S. Vlaisavljevic, and S. Trivic. 2011. Antioxidant capacity of Ocimum basilicum L. and Origanum vulgare L. extracts. Molecules 16:7401-7414.

Kottek, M., J. Grieser, C. Beck, B. Rudolf, and F. Rubel. 2006. World map of the Köppen-Geiger climate classification updated. Meteorologische Zeitschrift 15:259-263.

Love, D.C., J.P. Fry, L. Genello, E.S. Hill, J.A. Frederick, X. Li, and K. Semmens. 2014. An international survey of aquaponics practitioners. PLoS One 9:e102662.

Love, D.C., J.P. Fry, X. Li, E.S. Hill, L. Genello, K. Semmens, and R.E. Thompson. 2015. Commercial aquaponics production and profitability: Findings from an international survey. Aquaculture 435:67-74.

Phippen, W.B. and J.E. Simon. 1998. Anthocyanins in basil (Ocimum basilicum L.). J. Agr. Food Chem. 46:1734-1738.

Phippen, W.B. and J.E. Simon. 2000. Anthocyanin inheritance and instability in purple basil (Ocimum basilicum L.). J. Hered. 91:289-296.

Rakocy, J.E., D.S. Bailey, K.A. Shultz, and W.M. Cole. 1997. Evaluation of a commercial-scale aquaponic unit for the production of tilapia and lettuce, p. 357372. In: K. Fitzsimmons (ed.). Tilapia Aquaculture. Proc. Fourth Intl. Symp. Tilapia Aquacult., Orlando, FL.

Rakocy, J.E., D.S. Bailey, R.C. Shultz, and J.J. Danaher. 2011. A commercialscale aquaponic system developed at the University of the Virgin Islands, p. 336343. In: L. Liping and K. Fitzsimmons (eds.). Better science, better fish, better life. Proc. Ninth Intl. Symp. Tilapia Aquacult., Shanghai, China.

Rakocy, J.E., D.S. Bailey, R.C. Shultz, and E.S. Thoman. 2004a. Update on tilapia and vegetable production in the UVI aquaponic system, p. 676-690. In: R. Bolivar, G. Mair, and K. Fitzsimmons (eds.). New dimensions in farmed tilapia. Proc. Sixth Intl. Symp. Tilapia Aquacult., Manila, Philippines.

Rakocy, J.E., M.P. Masser, and T.M. Losordo. 2006. Recirculating aquaculture tank production systems: AquaponicsIntegrating fish and plant culture. Southern Reg. Aquaculture Ctr. Publ. 454:1-16.

Rakocy, J.E., R.C. Shultz, D.S. Bailey, and E.S. Thoman. 2004b. Aquaponic production of tilapia and basil: Comparing a batch and staggered cropping system. Acta Hort. 648:63-69.

Saha, S., A. Monroe, and M.R. Day. 2016. Growth, yield, plant quality and nutrition of basil (Ocimum basilicum L.) under soilless agricultural systems. Ann. Agr. Sci. 61:181-186.

Simon, J.E., M.R. Morales, W.B. Phippen, R.F. Vieira, and Z. Hao. 1999. Basil: A source of aroma compounds and a popular culinary and ornamental herb, p. 499-505. In: J. Janick (ed.). Perspectives on new crops and new uses. ASHS Press, Alexandria, VA.

Somerville, C., M. Cohen, E. Pantanella, A. Stankus, and A. Lovatelli. 2014. Small-scale aquaponic food production: Integrated fish and plant farming. FAO Fisheries Aquaculture Tech. Paper No. 589.

Timmons, M.B. and J.M. Ebeling. 2002. Recirculating aquaculture. 2nd ed. Northeastern Regional Aquacult. Pub. No. 01002.

Walters, K.J. 2015. Quantifying the effects of hydroponic systems, nutrient solution, and air temperature on growth and development of basil (Ocimum L.) species. Iowa State Univ., Ames, MS Thesis.

Walters, K.J. and C.J. Currey. 2015. Hydroponic greenhouse basil production: Comparing systems and cultivars. HortTechnology 25:645-650. 